\title{
超音波疲労試験によるオーステナイト系ステンレス鋼の 超高サイクル疲労強度評価*
}

\author{
高 橋 恭 平*1, 小 川 武 史 $^{* 2}$ \\ Evaluation of Giga-cycle Fatigue Properties of \\ Austenitic Stainless Steels Using Ultrasonic Fatigue Test
}

\author{
Kyouhei TAKAHASHI and Takeshi OGAWA*3 \\ *3 Department of Mechanical Engineering, Aoyama Gakuin University, \\ 5-10-1 Fuchinobe, Sagamihara-shi, Kanagawa, 229-8558 Japan
}

\begin{abstract}
Ultrasonic fatigue tests have been performed in austenitic stainless steel, SUS $316 \mathrm{NG}$, in order to investigate giga-cycle fatigue strength of pre-stained materials, i.e. 5,10 and $20 \%$ tensile prestrains and $-20 \%$ compressive pre-strain. The pre-strains were applied before specimen machining. The austenitic stainless steels are known to exhibit remarkable self-heating during the fatigue experiment. Therefore, heat radiation method was established by setting fatigue specimens in a low temperature chamber at about $-100^{\circ} \mathrm{C}$. The self-heating was controlled by intermittent loading condition, which enabled us to maintain the test section of the specimens at about room temperature. The results revealed that the fatigue strength increased with increasing pre-strain levels. Fish eye fracture was observed for $-20 \%$ pre-strained specimen fractured at $4.11 \times 10^{7}$ cycles, while the other specimens exhibited ordinary fatigue fracture surface originated from stage I facet on the specimen surface. The increase in fatigue limit was predicted by Vickers hardness, $H V$, which depended on the size of indented region. The prediction was successful using $H V$ values obtained by the size of the indented region similar to those of the stage I facets.
\end{abstract}

Key Words: Fatigue, Giga-cycle Fatigue, Hardness, Iron Steel, Ultrasonic Fatigue Test, Stainless Steels, Specimen Self-heating

\section{1. 緒言}

近年，高強度鋼やチタン合金について繰返し数 $10^{8}$ $\sim 10^{9}$ 回まで疲労試験を続行した場合に，107 回疲労限 度以下の応力において疲労破壊が起こり， $S-N$ 曲線 が再び下降することがあると報告されてきた ${ }^{(1)}$.これ は, 表面起点の破壊と材料内部の介在物などを起点と する破壊の 2 つの $S-N$ 曲線が存在するためであるこ とが明らかにされた．材料内部を起点とした $S-N$ 曲 線の検討を行うために, 幅広い材料系に対して超高サ イクル域での疲労強度評価を行うことが重要となって いる. 特に，オーステナイト系ステンレス鋼は，原子 力関連機器などの高い信頼性が要求される機械構造物 に多用されているにも関わらず，超高サイクル疲労強 度が十分に検討されていない.

$10^{9}$ 回の疲労試験を行うために, 繰返し速度が 100 $\mathrm{Hz}$ 程度の一般的な疲労試験機を用いた場合，3ヶ月以 上の時間が必要になる，それに対して，超音波疲労試

\footnotetext{
* 原稿受付 2006 年 4 月 17 日.

*1 青山学院大学大学院理工学研究科(画 229-8558 相模原市淵 野辺 5-10-1).

*2 正員, 青山学院大学理工学部.

E-mail : ogawa @ ocaoyama.ac.jp
}

験機を用いた場合， $20 \mathrm{kHz}$ の高速試験が可能となり， 14 時間程度で試験を完了できる. しかし, 超音波疲 労試験ではその高速振動による試験片の発熱が問題に なる. 特に, オーステナイト系ステンレス鋼は熱伝導 率が小さく, 材料の内部摩擦に基づく発熱が顕著な材 料であり，超音波疲労試験を行う場合には試験片から の放熱を十分に行うことが必要である. 試験片の温度 上昇を抑制する方法として, 超音波振動を間欠的に発 生させる方法が提案され, 高強度鋼などについて有効 性が確かめられている(2) (3).

本研究では超音波疲労試験機を自作し, 試験片の温 度上昇抑制方法の検討を行い, オーステナイト系ステ ンレス鋼の超高サイクル疲労強度の評価を行った．実 構造物に用いられる際には，塑性加工や溶接などによ り残留予ひずみが与えられている. オーステナイト系 ステンレス鋼は顕著な加工硬化を示す材料であり, 発 熱や超高サイクル疲労挙動に顕著な影響を及ぼすこと が予想される. そこで, 予ひずみを与えた試験片の超 高サイクル疲労試験を行い, 加工硬化と疲労限度の関 連について検討した. 


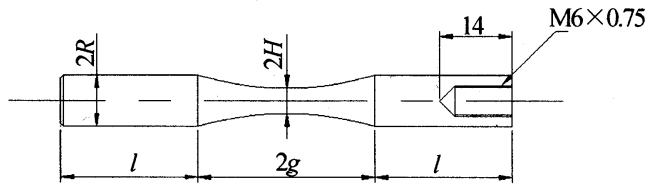

Fig.1 Ultrasonic fatigue specimen.

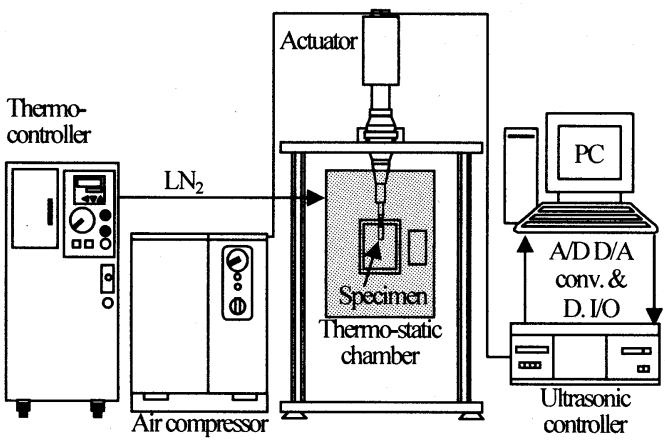

Fig.2 Ultrasonic fatigue testing machine.

\section{2. 材料および実験方法}

2-1＼cjkstart供試材および試験片＼cjkstart供試材はオーステナ イト系ステンレス鋼 SUS304 および SUS316NG である. SUS304 は市販の JS 相当材料で, 試験方法の検討につ いて用いた. SUS31@NG は原子力用熱間圧延ステンレ ス鋼であり，化学成分(mass\%)は C: 0.014, Si: 0.39, Mn: 1.42, P: 0.029, S: 0.001, Cr. 17.44, Ni: 12.21, Mo: 2.14, N: 0.11, $\mathrm{C}+\mathrm{N}: 0.12$, Fe: Bal.である. 機械的性質は, 0.2\%耐力：

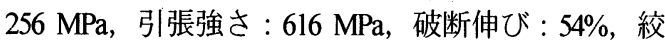
り：86\%である. 予ひずみの影響を検討するために, 試験片を加工する前に引張予ひずみ 5,10 および 20\%, 圧縮予ひずみ一20\%を真ひずみに基づき与えた．試験 片形状は図 1 のような砂時計型である。試験片寸法は 式(1) (3) (4) より. $20 \mathrm{kHz}$ で共振する寸法を求め, 機械加 工を行った.

$$
\begin{aligned}
& l=\frac{c}{\omega} \tan ^{-1}\left[\frac{c}{\omega}(\beta \operatorname{coth} \beta g-b \tanh b g)\right] \\
& b=\frac{1}{g} \cosh ^{-1}\left(\frac{R}{H}\right) \\
& \beta=\sqrt{b^{2}-\left(\frac{\omega}{c}\right)^{2}}
\end{aligned}
$$

ここで，cは縦波速度， $\omega$ は角速度である.

オーステナイト系ステンレス鋼の一般的な縦弾性係 数 $E=190 \mathrm{GPa}$ を用いて寸法を決定し, 試験片の機械
加工を行った. 図 1 において, $l=26.6 \mathrm{~mm}, 2 g=34.3$ $\mathrm{mm}, 2 H=5 \mathrm{~mm}$ および $2 R=10 \mathrm{~mm}$ である. ところが, 試験応力振幅よりも十分小さい条件で予備的な共振確

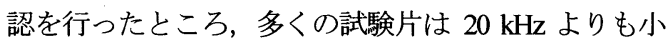
さい共振点を示した. そこで, $20 \mathrm{kHz}$ で共振するよう に, $l$ を個々の試験片について調整した. 共振調整後 の試験片寸法から逆算すると, 多くの試験片が $E=$ $150 \mathrm{GPa}$ 程度であった. $E=190 \mathrm{GPa}$ 程度の試験片も含 まれていたが，以下の試験からは除外した。 なお， $E$ の差異は材質に基づくものであるが，その原因は明ら かでない，試験片表面にはエメリー紙( \#1500)を用 いて軸方向研磨を施した. 試験片中央部には温度履歴 の測定を行うために $\mathrm{T}$ 型熱電対を接着剤により貼り 付け， $0.1 \mathrm{sec}$ ごとに試験片温度を測定した.

2-2 試験機および実験方法 疲労試験は, 自作 した超音波疲労試験機によって行った. 試験機の概要 を図 2 に示す．超音波の発振には BRANSON 社製ピエ ゾアクチュエータとパワーサプライ(2000bdc)を使用し た. アクチュエータの発振周波数は $20 \mathrm{kHz}$ であり, $\pm 500 \mathrm{~Hz}$ の共振追従範囲がある. また, ホーンの端面 振幅範囲は $\pm 0 \sim 50 \mu \mathrm{m}$ である. 試験応力振幅は, 試験 片端面変位振幅 $a$ から式(4)により算出した.

$$
\sigma_{\mathrm{a}}=a \cdot E \cdot \beta \cdot \cos \left(\frac{\omega \cdot l}{c}\right) \cdot \cosh b g \cdot\left(\frac{1}{\sinh \beta g}\right)
$$

試験開始前に $a$ とアクチュエータ・コントローラから の振幅出力の関係を校正した. $a$ の測定には渦電流変 位センサーを用いた.

超音波疲労試験では，その高速振動により試験片 が発熱し，一般的な疲労試験とは異なる結果となる. そこで，試験片の温度上昇を抑制させるために，超音 波の発振と停止を繰り返す間欠運転が行われている (2) (3). オーステナイト系ステンレス鋼では, 回転曲げ 疲労試験中にも顕著な発熱が観察され，大気中よりも 水中の疲労限度が高くなることが知られている ${ }^{(5)}$.ま た, 熱伝導率も低いことから, 試験片の温度上昇を抑 えることが極めて重要である. 本研究では, 間欠運転 条件を自由に設定できる自作の超音波疲労試験機を用 いて，試験片の温度上昇の抑制を目的とした放熱につ いて，以下に示す方法を検討した。 (1)間欠運転の停 止時間を長くする方法, (2)試験片中央部に空気を吹 き付ける方法, (3)試験片雾囲気温度を低温状態にす ることで試験片の最大温度を室温程度に抑える方法で ある. なお，放熱の点では水冷が有効であるが，超音 波疲労試験では試験片表面にキャビテーションが発生 し，そのエロージョン痕が疲労き裂発生起点となる ${ }^{(0)}$. 

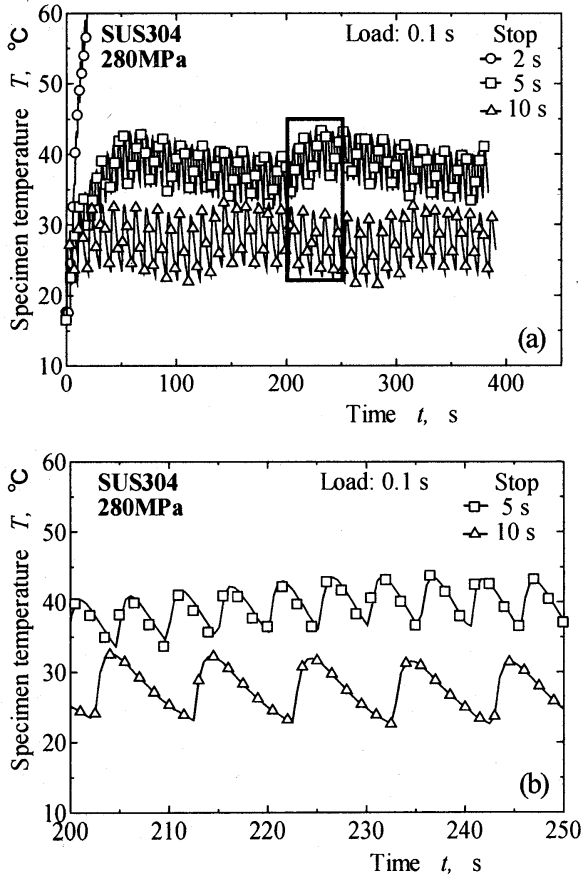

Fig.3 Variations of specimen temperature of SUS304 during ultrasonic fatigue tests for $t=0-450 \mathrm{~s}$ (a) and $t=200-250 \mathrm{~s}(\mathrm{~b}$ ), showing the influence of loading interval.

\section{3. 放熱方法の検討結果}

SUS304 を用いて超音波疲労試験方法の検討を行つ た. 応力振幅 $\sigma_{\mathrm{a}}=280 \mathrm{MPa}$ において, 試験片の発熱状 態の観察を行った.

3-1 間欠運転の停止時間の影翌 間欠運転条件 を変化させて試験片の温度変化を調べた．試験片の中 央部には，コンプレッサーから圧縮空気を吹きつけて 冷却した。 発振時間 $t_{\mathrm{L}}=0.1 \mathrm{~s}$ を一定として，停止時間 $t_{s}=10,5$ および $2 \mathrm{~s}$ と変化させたときの試験片中央部の 温度 $T$ の履歴を図 3 に示寸. 図 3(a)において, 温度変 化がほぼ定常状態となった時間 $t=200 \sim 250 \mathrm{~s}$ の温度履 歴を拡大して図 3(b)に示した. 図 3(a)から明らかなよ うに, $t_{\mathrm{s}}=2 \mathrm{~s}$ では $T$ が単調に増加し, $50^{\circ} \mathrm{C}$ を超えたの で試験を停止した. $t_{\mathrm{S}}=5 \mathrm{~s}$ では $T$ 最大值を $40^{\circ} \mathrm{C}$ 程度, $t_{\mathrm{S}}=10 \mathrm{~s}$ では $30^{\circ} \mathrm{C}$ 程度に抑えることができた.

図3(b)から，超音波が発振した瞬間に試験片最小断 面部の温度は急上昇し，停止時間に周辺部一放熱され ている.この発熱と放熱が平衡状態になったときの試 験片最大温度を間欠運転によって制御することは可能 である，なお，結果は省略するが，圧縮空気による試 験片中央部の冷却を行なわないと, $t_{\mathrm{L}}=0.1 \mathrm{~s}$ および $\mathrm{s}_{\mathrm{s}}=$
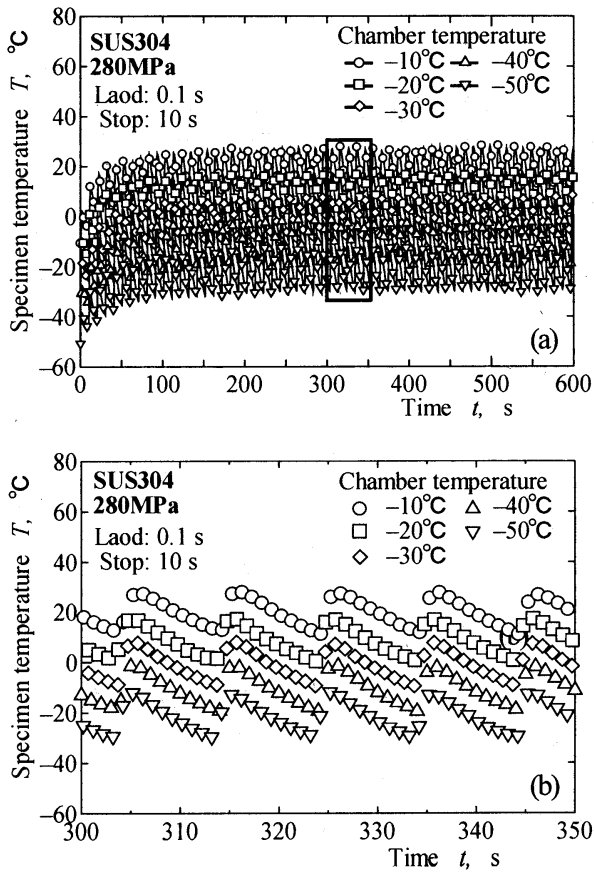

Fig.4 Variations of specimen temperature of SUS304 during ultrasonic fatigue tests for $t=0-600 \mathrm{~s}$ (a) and $t=300-350 \mathrm{~s}(\mathrm{~b})$, showing the influence of chamber temperature.

$10 \mathrm{~s}$ の条件でも試験片温度が急上昇し, 疲労試験を継 続できなかった. 一方, コンプレッサーと空気吐き出 しロの間にボルテックスチューブ(サンワ・エンター プライズ(株)製，COLDER)を設置し，圧縮空気の温 度を低下させると, 試験片の温度は図 3 の結果よりも $10^{\circ} \mathrm{C}$ 程度低下し, ある程度の効果が認められた。 しか し, 停止時間が長いと超音波疲労試験の特徵である高 速疲労試験が行えなくなる. したがって，さらに放熱 を促進させる方法を組み合わせて超音波疲労試験を行 う必要がある。

3-2 低温槽による試験片の放熱 超音波疲労試 験機に最低槽内温度 $-180^{\circ} \mathrm{C}$ の低温槽(コレット工業 (株)製・クライオサーモ)を取り付けた。これにより， 試験片の雾囲気温度を下げることで, 試験片の放熱を 促進させることを検討した. 間欠運転条件は $t_{\mathrm{L}}=0.1 \mathrm{~s}$ および $t_{\mathrm{S}}=10 \mathrm{~s}$ とし, 低温槽内温度を変化させて試験 片中央部の $T$ を測定した. 図 4 に試験中の温度履歴を 示した. 図 4(b)には, 試験片温度が定常状態となった $t=300 \sim 350 \mathrm{~s}$ を拡大して温度履歴を示した. 図4(a)か ら, 槽内温度が- $20^{\circ} \mathrm{C}$ の場合に $T$ の最大值が約 $20^{\circ} \mathrm{C}$ になっており，COLDER を使用した空冷を行ってい るときの放熱状態とほぼ同程度であった．また，槽内 


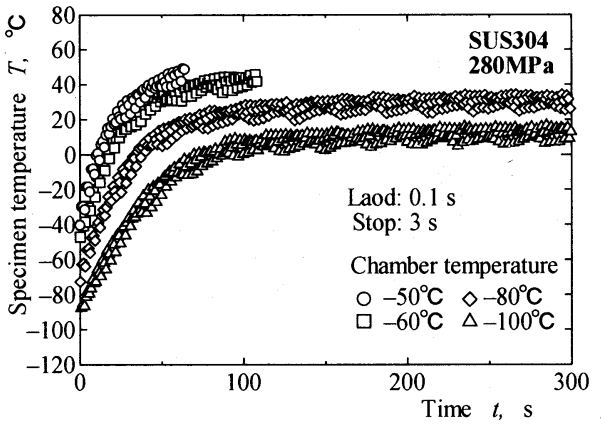

Fig.5 Variations of specimen temperature of SUS304 during ultrasonic fatigue tests for the loading interval of $3 \mathrm{~s}$, showing the influence of chamber temperature.

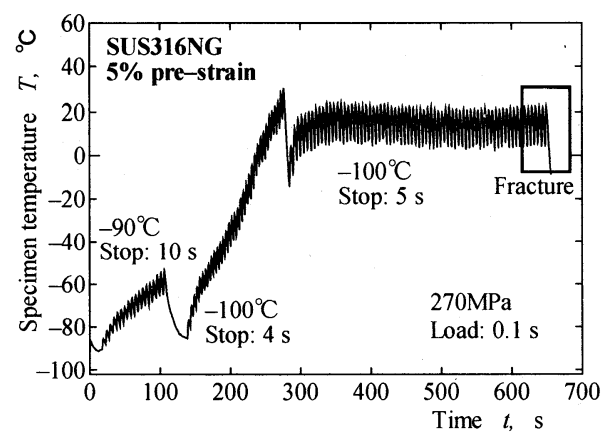

Fig.6 Variations of specimen temperature of SUS316NG with $5 \%$ pre-strain during ultrasonic fatigue test.

温度を低下させるに伴い， $T$ は槽内温度と同程度低下 した. すなわち，槽内温度が低下しても発熱の抑制は できず，相対的に $T$ を低温側にシフトした状態となっ ている.

$t_{\mathrm{L}}=0.1 \mathrm{~s}$ および $t_{\mathrm{S}}=3 \mathrm{~s}$ として, 同様の疲労試験を行 ったときの試験片温度を図 5 に示す．図 4 と同様に, 超音波が発振されるたびに試験片温度は上昇したが, 槽内温度を下げることによって $t_{\mathrm{s}}$ を小さくして試験を 行なうことが可能となった，以上の結果に基づき，疲 労試験条件に合わせて，試験中の停止時間および槽内 温度を調節することによって，試験片中央部の温度を 室温程度にすることが可能となった。この方法により, 以下に示す SUS316NG の超音波疲労試験を行なった.

\section{4. 超音波疲労試験結果}

SUS316NG の 5，10，20(引張)およびー20\%(圧縮) 予ひずみ材に対して超音波疲労試験を行った. 疲労試 験中の試験片温度履歴の一例として，5\%予ひずみ材 の $\sigma_{\mathrm{a}}=270 \mathrm{MPa}$ の結果を図 6 に示す。試験片の最大温 度を $20 \sim 30^{\circ} \mathrm{C}$ 程度に安定させるように，試験中に停止

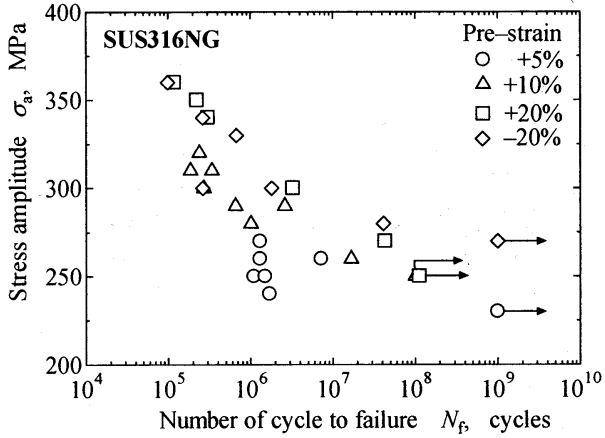

Fig.7 $S$ - $N$ curves of SUS316NG with various pre-strains.

時間および低温槽温度を適宜変更し, 試験片中央部の 温度を調節した.

このような試験によって得られた $S-N$ 曲線を図 7 に示す．以上の放熱方法によって SUS316NG の室温の 超音波疲労試験が可能となり, 破断直前まで顕著な試 験片温度の上昇を伴わずに $10^{8} \sim 10^{9}$ 回に至る疲労試験 を行うことができた．なお，破断の直前には，大きく 成長した疲労き裂先端の塑性域で顕著な発熱が生じ, 局所的な酸化着色が観察された. 図 7 の $S-N$ 曲線か ら，予ひずみの増加に伴って疲労強度が上昇すること がわかる．また，圧縮および引張予ひずみ材の結果に 顕著な差異は認められないが, 疲労限度 $\sigma_{w}$ は圧縮予 ひずみ材のほうがやや高い.

疲労破面の観察を行った結果, 後述の 1 例を除き 表面起点の疲労破壊であり, 起点部分には $10 \mu \mathrm{m}$ 程 度の大きさの第 I 段階ファセットが観察された. SUS304 の疲労限度近傍の疲労試験において, 停留き 裂の観察されることが報告されているが， $10 \mu \mathrm{m}$ 以下 の寸法であり (7)，疲労限度は第 I 段階き裂の進展限界 を意味していた. 本研究の SUS31@NGにおいても同様 であると考えられる.

一方， $-20 \%$ 予ひずみ材の $\sigma_{\mathrm{a}}=280 \mathrm{MPa}$ の試験にお いて, 破断繰返し数 $N_{\mathrm{f}}=4.11 \times 10^{7}$ 回の試験片では, 図 8 に示すような試験片内部を起点としたフィッシュア イ破壊が観察された. しかし，フィッシュアイの中央 部を高倍率て観察しても介在物は認められず，EPMA を用いた元素分析でも偏析は認められなかった. 他の 予ひずみ材において， $N_{\mathrm{f}}>10^{7}$ 回となる試験片が存在 するが，これらの破面はいずれも表面起点であった. したがって，図 8は特異な例であることも考えられる が，オーステナイト系ステンレス鋼にも材料内部を起 点とした超高サイクル疲労挙動が存在することを示唆 するものであり, 今後の詳細な検討が求められる. 

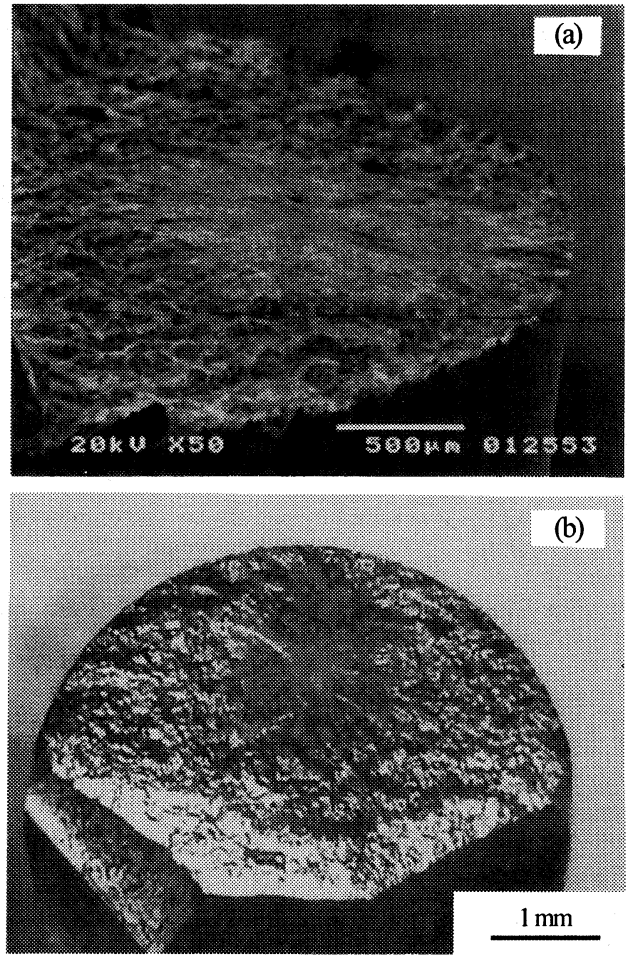

Fig.8 Fracture surface with fish-eye observed on $-20 \%$ pre-strained material: side view by scanning electron microscope (a) and top view by optical microscope (b).

\section{5. 考 察}

図 7 に示したように，疲労強度に及ぼす予ひずみの 影響は，引張または圧縮にかかわらず生じており， $20 \%$ 予ひずみ材と $-20 \%$ 予ひずみ材の $S-N$ 曲線は， $\sigma_{\mathrm{w}}$ がわずかに異なることを除き，ほぼ一致していた：こ れは，疲労強度の上昇がひずみ硬化に起因するためと 考えられる. そこで，予ひずみ材のビッカース硬さ $H V$ を詳細に測定した. 得られた結果を図 9 に示す. 試験方法の詳細は別報 ${ }^{(8)}$ に示すが，試験機のコンプラ イアンスや圧子の先端形状などに起因する $H V$ の寸法 効果(押込み力 $F$ による影響)は，補正によって除外さ れている.この補正は，W， Mo， Fe， Alおよび Ni の 単結晶において $H V$ の寸法効果が最小となるようにし ているものである. ロットの異なる SUS310NGの予ひ ずみを与えていない試験片について $H V$ を測定したと ころ，HVは $F に$ 依存せず，ほぼ一定であつた.

図 9 の試験には，超音波疲労試験に先立つて行う共 振周波数調整において切断された試験片の肩部を試験 片として用いた. 用いた硬さ試験機は， $F=2 \mathrm{~N} \sim 20 \mathrm{~N}$ に対してビッカース硬度計 HMV2000, $F=50 \mathrm{mN} \sim 1 \mathrm{~N}$

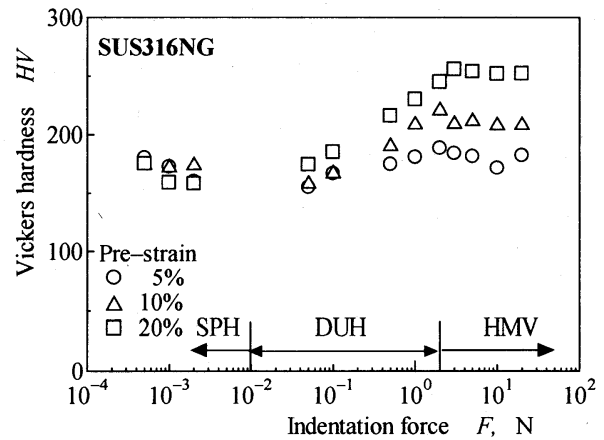

Fig.9 Vickers hardness, $H V$, for pre-strained materials showing the influence of indentation force, $F$.

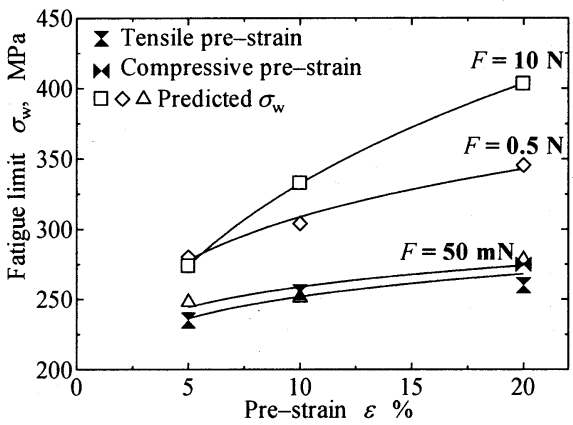

Fig.10 Comparison of fatigue limit, $\sigma_{\mathrm{w}}$, compared with those predicted by $H V$ obtained by various $F$ values.

に対してダイナミック超微小硬さ試験機 DUH-W201, $F=500 \mu \mathrm{N} \sim 2 \mathrm{mN}$ に対してナノスコピック表面検査装 置 SPH-1 であり，いずれも島津製作所(株)製である. $F$ の大きい範囲では予ひずみが大きいほど $H V$ が大き く，ひずみ硬化の影響が現れているが，F の低下に伴 ってその影響は消失している.この原因は別報に示す が，転位組織の寸法と関連している. 長島らも同様の 結果を報告している ${ }^{(9)}$.

一般に, $H V$ と疲労限度 $\sigma_{\mathrm{w}}$ はよい相関関係を示すこ とが知られており, 次式の関係がある ${ }^{(10)}$.

$$
\sigma_{\mathrm{w}}=1.6 H V
$$

図 9 に示した $H V$ の結果を式(5)に適用して予測された $\sigma_{\mathrm{w}}$ を図 7 の実験結果と比較して図 10 に示す. $H V$ は $F$ に依存することから，F=10 N, $0.5 \mathrm{~N}$ およひ $50 \mathrm{mN}$ ついて $\sigma_{\mathrm{w}}$ の予測值を示している. $\sigma_{\mathrm{w}}$ の実験結果は $F=$ $50 \mathrm{mN}$ の予測值とほぼ一致しており, マクロなひずみ 硬化から予測される $\sigma_{\mathrm{w}}$ の上昇よりもかなり小さい. $F$ $=50 \mathrm{mN}$ の硬さ試験における圧痕寸法は $10 \mu \mathrm{m}$ 程度で ある. この寸法は, 破壊起点部に観察された第 I 段階 ファセットと同程度である. 前述したように, 疲労限 
度は第 I 段階き裂の進展限界を意味していると考えら れるので， $H V$ に寸法効果が見られる場合には， $\sigma_{w}$ の 支配現象と同程度の寸法レベルの圧痕で測定された $H V$ を用いて疲労限度の推定を行うことが必要である。

\section{6. 結 言}

本研究では，オーステナイト系ステンレス鋼に対 して超音波疲労試験を行い, 疲労強度に及ぼす予ひず みの影響を明らかにした．得られた主な結果は以下の とおりである.

(1) 発熱挙動の観察と放熱方法についての検討を 行い，超音波疲労試験を可能にした．試験片全体を一 $100^{\circ} \mathrm{C}$ 程度の低温槽内に入れ, 自己発熱によって試験 片中央部が室温程度となる条件で疲労試験を行った。

(2) 上記の疲労試験により, 超高サイクル域の疲 労強度に及ぼす予ひずみの影響を明らかにした．予ひ ずみの増加に伴って疲労寿命は増大し, 疲労限度が上 昇した.

(3) $-20 \%$ 予ひずみ材では， $10^{7}$ 回以上の超高サイ クル領域の絽返し数で, 材料内部を起点としたフュッ シュアイ破壊が観察された，他の試験片では，表面を 起点とした疲労破壊が生じ, 起点部には第 I 段階ファ セットが観察された.

(4) 予ひずみの増大に伴ってビッカース硬さ $H V$ が上昇するが， $H V$ には顕著な圧痕寸法(押込み力)依 存性が認められた. 疲労限度の上昇は第 I 段階ファセ ット寸法と同程度の圧痕で測定された $H V$ からの予測 と一致した。

本研究は東京電力 (株)の委託による(社) 日本溶接協 会原子力研究委員会 GCF2 小委員会 (主査 : 小林英男 横浜国立大学教授)で, 著者等の分担したラウンドロ ビン試験の成果の一部である. 東京電力(株)をはじめ 関係各位に感謝寸る.

\section{文 献}

(1) Ochi, Y. and Sakai, T., Fatigue of Metallic Materials in the Very High Cycle Regime (in Japanese), Journal of the Society of Materials Science, Japan, Vol.52, No.4 (2003), pp.433-439.

(2) Ishi, H. et al., Giga-Cycle Fatigue Strength in Some High Strength Steels by Ultrasonic Fatigue Testing, Materials
Science Research International, Special Technical Publication-1 (2001), pp.59-63

(3) Ishi, H. et al., Evaluation of Giga-cycle Fatigue Properties of Some Maraging Steels by Intermittent ultrasonic Fatigue Testing, Fatigue and Fracture of Engineering Materials and Structures, Vol.25 (2002), pp.831-835.

(4) Salama, K. and Lamerand, R. K., The Prediction of Fatigue Life Using Ultrasound Testing, Proceedings of the First International Conference on Fatigue and Corrosion Fatigue Up To Ultrasonic Frequencies, (1981-10), pp. 109-133.

(5) Tokaji, K et ai, Fatigue strength of austenitic stainless steel in various environments: Initiation, density and distribution, and growth of small fatigue cracks (in Japanese), Journal of the Society of Materials Science, Japam, Vol.34, No.382 (1985), pp.816-822.

(6) The GCF2 (Giga Cycle Fatigue Phase 2) Subcommittee, Research on High Cycle Fatigue Strength of Power Plant Component Material (in Japanese), (2005), p.46-54, The Japan Welding Engineering Society.

(7) Ogawa, T. et al., High Cycle Fatigue Properties of SUS 304 Stainless Steel under Load-Increasing Conditions (in Japanese), Transactions of the Japan Society of Mechanical Engineers, Series A, Vol.65, No.636 (1999), pp.1684-1689.

(8) Ohno, T and Ogawa, T, Low Temperature Strength and Micro-mechanical Properties of Austenitic Stainless Steel (in Japanese), Proceedings of M\&M Conference of the Japan Society of Mechanical Engineers, (2005), pp.293-294 (2005).

(9) Nagashima, $\mathrm{N}$ and Matsuoka, S., Nano-meso-macro Analysis of Strength of Fatigue Loaded SUS316L (in Japanese), Proceedings of M\&M Conference of the Japan Society of Mechanical Engineers, (2005), pp.191-192.

(10) Nakai Y. et al., Strength and Fracture of Materials (in Japanese) (2005), p.93, the Society of Materials Science, Japan. 